Anna Węgrzyniak

\title{
Ćwiczenie ekologicznej wyobraźni. O poezji Julii Fiedorczuk
}

W odbiorze wierszy Julii Fiedorczuk (rocznik 1975), która specjalizuje się w amerykańskim modernizmie i propaguje w Polsce ekokrytykę, pomocne okazują się prace teoretyczne: esej napisany wspólnie z Gerardo Beltránem zatytułowany Ekopoetyka oraz dzieło autorskie Cyborg w ogrodzie. Wprowadzenie do ekokrytyki. Tytul pierwszego tomu poetyckiego, Listopad nad Narwia (2000), za który adeptka sztuki poetyckiej otrzymała nagrodę Polskiego Towarzystwa Wydawców Książek za najlepszy debiut (Poznań, 2002), jeszcze nie kieruje uwagi odbiorcy w stronę eko, natomiast wszystkie następne tytuly - lakoniczne i precyzyjne: Bio (2004), Planeta rzeczy zagubionych (2006), Tlen (2009), tuż-tuż (2012) - już ekopoezję (ani nurt, ani kierunek, zjawisko modne na Zachodzie, w Polsce słabo obecne) zapowiadają. Ekokrytyka jest sposobem czytania zorientowanym na relację człowiek-środowisko (środowisko naturalne, ale i miejskie, bo kategorię „natura” ekokrytycy zastępują „środowiskiem”), bywa definiowana jako punkt stykania się form literackich i nieliterackich, tworzenie metafor kojarzących humanistykę z naukami ścisłymi i przyrodniczymi. Prawdę mówiąc, taki wyróżnik do mnie nie przemawia, 
bo mieszanie się form jest zjawiskiem powszechnym i występuje w poezji niemającej żadnych związków z programem „eko”. Zanim podjęłam trud lektury, by przyjrzeć się praktyce ekopoetyckiej, przestudiowałam deklarowany „program” ekopoetyki, który dla uproszczenia sprowadzam do najważniejszych kwestii.

Założenie wstępne wynika z naukowej diagnozy złej kondycji naszej planety i kosmosu. Wobec postępującej degradacji środowiska naturalnego sztuka/poezja przyjmuje zadanie współtworzenia „wyobraźni ekologicznej” - ma budzić świadomość związku ludzkiego z nie-ludzkim, ma podjąć próbę rozdzielenia poezji i nauki. „Życie, jak sugeruje biosemiotyka, może wiązać się z procesami semiozy (tworzenia i interpretowania znaczeń) na najbardziej podstawowym poziomie materii” [Fiedorczuk, Beltrán 2015: 17]. Biosemiotyka, młoda gałąź nauk przyrodniczych, ma charakter interdyscyplinarny, korzysta z ustaleń neurobiologii, embriologii, biologii ewolucyjnej, biofizyki, a także nauk humanistycznych (np. językoznawstwa) i trudno jednoznacznie wiązać ją z posthumanizmem, czego świadectwem jest praca Adama Kłósia Od neuronu do kultury - biosemiotyczna historia powstawania i ewolucji mózgu według Marcello Barbieriego. Dzisiaj już wiemy, że podstawę wszystkich procesów życiowych, na każdym poziomie, stanowi wymiana informacji, że

język jest jedną z wielu postaci aktywności semiotycznej prowadzonej bez ustanku przez wszystkie żywe istoty. Jak pisze Wheeler, „ludzie rozwinęli zdolność do metaforycznej abstrakcji polegającej na improwizowaniu i nadawaniu konkretnemu tematowi większej złożoności. Jednak to, co nazywamy metaforą (rozpoznanie podobieństwa, czyli odpowiedniości, w różnicy), jest właściwością życia od samego początku”. [Fiedorczuk, Beltrán 2015: 57]

Biosemiotyka łącząca procesy semiotyczne z życiowymi (język jest zakorzeniony w ciele) wiąże się zatem z materialnością języka, a język - pisze bliska Fiedorczuk poetka Laura Riding Jackson - to jedyna przestrzeń, w której się spotykamy, „to nasz wspólny dom” [Jackson 2012: 111]. Innym domem jest ziemia. Od greckiego oikos 
(początkowo oznaczało „wspólną przestrzeń” i „gospodarstwo domowe”) pochodzą słowa ekologia i ekonomia. „A zatem jeśli ekologia to «wiedza o domu», a ekonomia - «reguly zarządzania domem», to ekopoetyka jest «tworzeniem domu»" [Fiedorczuk, Beltrán 2015: 85]. Postulując nie-logocentryczne zamieszkiwanie Ziemi (inaczej niż to ujmował Martin Heidegger), autorzy eseju radzą przenieść uwagę z ,ja” na otaczający świat. Ich propozycja ambitnie zakłada przebudowę świadomości, jest próbą stworzenia nowej epistemologii, nowej etyki. Czy tak utopijny program ma szanse realizacji - można o tym dyskutować.

Lektura wierszy Fiedorczuk jest niełatwa - poetka chętnie posługuje się aluzją, nadużywa metafory, wprowadza cytaty z poezji anglojęzycznej, stosuje pojęcia z zakresu mikrobiologii, psychoanalizy, fizyki, biochemii i innych dyscyplin. Trudno nazwać tę poezję „uczoną” w takim sensie, jaki przypisujemy pojęciu poeta doctus. Uważna lektura trudniejszych partii wymaga korzystania z usług Wikipedii - do tego „źródła” odsyła sama autorka, niejako podpowiadając odbiorcy, skąd czerpie wiedzę [zob. np. Burze i przejaśnienia, T]. Jej niekwestionowaną zasługą jest zwrócenie uwagi odbiorcy na rewolucyjne „odkrycia” (bozon, Neutrino, Fort da Freuda ...).

Każde czytanie zaczynam od namysłu nad tytułem, który traktuję jako pierwszy, najważniejszy klucz do interpretacji. Bio przez odniesienie do bios (gr. życie) przywołuje pojęcia: biosfera, biologia, biocenoza. Planeta rzeczy zagubionych zapowiada wiersze o Ziemi $\mathrm{i}$ utracie. Tlen wprowadza $\mathrm{O}_{2}$ - pierwiastek chemiczny powszechnie obecny na Ziemi i w ziemskiej atmosferze, niezbędny do życia większości organizmów, a tuż-tuż kojarzy się z szybkim nadejściem czegoś. Szereg pojęć użytych w tytułach kolejnych tomów: bio planeta - tlen - tuż-tuż układa się w scenariusz zagłady życia. Zgodnie z programem ekologii Fiedorczuk uczula odbiorcę na to, o czym dzisiaj krzyczą ekolodzy. Życie planety jest zagrożone, lasy nie nadążają z dostarczaniem tlenu, emisja gazów cieplarnianych grozi degradacją biosfery, dziura ozonowa przyspiesza mordercze działanie słońca, koniec naszej planety jest blisko („tuż-tuż”).

Już w tomie Bio poetka ujawnia ekocentryzm (inaczej biocentryzm), na różne sposoby daje wyraz przekonaniu, że człowiek 
jest nieuprzywilejowanym elementem biosfery, jedną z wielu istot zamieszkujących Ziemię. Fiedorczuk wprawdzie podejmuje próbę rezygnacji z postawy antropocentrycznej, ma jednak świadomość klęski. Wie, że taki projekt się nie uda, bo mówiąc o przyrodzie, poeta zawsze mówi o sobie. A jednak próbuje - „organiczne” metafory łączą tkankę żywego organizmu z tkaniną artysty, który splata wątek ciała/materii z terminami nauk przyrodniczych i aluzjami do dzieł sztuki. Jej program poetycki znakomicie zostaje wyłożony w finale Fotosyntezy - zieleń łączy oko z wodą, a ostatnie zdanie w rytmie wyliczenia instrumentacyjnie „wybija” trzy słowa klucze, których fonetyczne podobieństwo eksponuje wagę tlenu i nierozerwalny związek bio-tkanki z tkaniną artysty: „Zieleń tęczówki jak morze. / Tkanka, tkanina, tlen"1 $[\mathrm{B}]$.

Tkanka żywego organizmu, ale też tkanka-tkanina prowadzą odbiorcę w stronę „biocenu”: „Kiedy byłam rybą / Nie było w ogóle dni, / Seksu, ani różnicy” [Bio, B]. Podmiot wierszy Fiedorczuk często cofa się do prehistorii planety, tęskni do formy wolnej od ograniczeń, żyjącej poza świadomością, czasem i zróżnicowaniem płciowym - jak ryba zamieszkująca dom wodny. Motyw ryby pojawia się tutaj wyjątkowo często, a wyobraźnią materialną poetki - jak by to ujął Gaston Bachelard - włada woda (snu, marzenia, melancholii), żywioł pierwszy i ostatni, bo życie z wody wyszło i do wody/stanu niezróżnicowania powraca. Ryba jest znakiem szczególnie ważnym. Można by wskazać sieć „rybnych” aluzji łączących Fiedorczuk z bliskimi jej poetkami; na przykład w wierszu Obroty cudów, od którego bierze tytuł przygotowany przez nią wybór wierszy Laury Jackson, czytam: „ryba, / Lepszy człowiek, / ślizgać się będzie / Antropocentrycznie, w żałobnych płetwach / Dla upamiętnienia / Much prawie cudownego ostatniego tchnienia" [Jackson 2012: 39].

W poezji Fiedorczuk osoba mówiąca zazdrości rybie obojętności, swobody i „domu” bez ścian. W licznych intertekstualnych odniesieniach poetka przywołuje cytaty i kryptocytaty z motywem ryby. Trzeba też uwzględnić jej wskazówkę na okładce książki, gdzie umieściła cytat z Ziemiomorza Ursuli K. Le Guin: 
„Ryby Morza Otwartego / nie znają swoich imion / i nie zważają na czary”. Lokalizuję te ryby w części 10 zatytułowanej Morze Otwarte [Le Guin 2013: 150]. Żeglarzy płynących poza archipelag sztorm znosi w obszary niezamieszkałe przez ludzi. Tylko tam, gdzie nie ma żadnego lądu, ich czary nie działają - na Morzu Otwartym, nieskażonym ludzką czy czarodziejską siłą, ryby są wolne, bezimienne. I właśnie taka ryba - nieobciążona żadną symboliką, żyjąca w oceanie, z którego jeszcze nie wyłoniła się ziemia - ma dla poetki znaczenie szczególne. Jej ryby - zajmujące jedno z pierwszych miejsc w łańcuchu ewolucji - mieszkają w płynnej przestrzeni ciemnych wód, a jako spadkobierczynie ciemności najlepiej reprezentują nie-ludzką rzeczywistość. Motyw ryby „podwójnie niemej” pojawia się w eseju przy okazji lektury wiersza Marii Brandy, w którym określenie „podwójnie niema” jest aluzją do barokowego poematu Meksykanki Juany Inés de la Cruz (tylko senna wizja rozjaśnia „noc”, w której żyją ryby) [Fiedorczuk, Beltrán 2015: 24-25].

W rzece Heraklita Wisławy Szymborskiej „ryba pojedyncza”, „odrębna”, wyemancypowana z natury, lękając się ciemności, pisuje „małe ryby”. Tu podobnie z opowieścią o pradziejach gatunku koresponduje fragment Fotosyntezy: „trzeba wyjść na ląd, opierzyć się i patrzeć / prosto w słońce” [B], w którym przy okazji słychać echo wczesnych wierszy Szymborskiej (ryba zgubiła ogon, zapuściła skrzydła, wyszła na ląd, spojrzała w niebo). Może to jednak przypadek, wszak myślenie ewolucyjne, w które wyposaża nas szkoła, jest dzisiaj powszechne.

W przywołanym monologu, a także w innych wierszach zwracam uwagę na obrazowanie eksponujące proces, w którym stratę równoważy zysk. Poezja Fiedorczuk często przypomina obowiązujące w przyrodzie prawo ekonomii. W omawianym utworze z rybą rekompensatą za utratę ogona jest „para bolesnych stóp”. Przykłady można mnożyć.

Człowiek z wierszy Fiedorczuk stale balansuje pomiędzy poczuciem przynależności do miejsca we wspólnym „domu” (to wyraża się eko-gotowością do oswajania „niemej ryby”) a brakiem akceptacji panujących w nim praw (lęka się ciemności, czyli „rybiego” powrotu do stanu niezróżnicowania). Niepogodzony 
z kruchością życia, przeciwwagi dla lęków szuka w sojuszu poezji z nauką. Bohaterka liryczna tomu Bio czuje związek ze światem dzięki ciału poddawanemu procesom zachodzącym w świecie organicznym. Tytułowa „fotosynteza” to określenie jednego z podstawowych procesów biochemicznych przemian (z materii nieorganicznej w organiczną) - pod wpływem światła rośliny wyposażone w chlorofil wytwarzają pokarm i rosną. Przywołany w wierszu proces fotosyntezy trzeba rozumieć metaforycznie światło słońca scala, składa, leczy: „na stopie mam plasterek ciepła”, „na powiekach lekki kompres krwi”. Aktywność słońca przywraca psychofizyczną równowagę, mobilizuje organizm do życia, do myślenia o „Wielkim Wylewie Ultramaryny”, o tajemniczym Początku. W tę stronę prowadzą nauka i ekologiczna wyobraźnia, angażująca ciało (to, co pod skórą) i język do pokonania przepaści czasu:

i coraz mocniej trę oczy. Tamte podskórne czasy podpływają bliżej, są moje

na ułamek światła, momentalny bezdech i rozkoszny strach, który się zaraz rozproszy w musującej toni. Mieć ciebie świecie na własność. Kochać cię, ciebie tracić. [Fotosynteza, B]

Ten momentalny powrót do stanu istnienia bez-świadomego nazywam ciemną epifanią. Człowiek zanurza się tutaj w „musującej toni” jak Leśmianowski „topielec zieleni”, z tą różnicą, że wpadając w topiel, wraca do świata istot żywych. Poetka nie używa słowa „byt”, nie zajmuje się metafizyką. Bohaterka Fotosyntezy chce kochać świat taki, jaki on jest, widmo na powiece kojarzy z ukwiałem, który jej „opowiada barwne ichtiologiczne historie”.

„Momentalny bezdech” wywołuje emocje określane oksymoronem „rozkoszny strach”. Ludzki strach przed śmiercią i nie-ludzka rozkosz zanurzenia się w „musującą toń” topieli.

Zawieszeni na „wydechu świata” tak długo jesteśmy, jak długo oddychamy i kochamy: „Usta przy policzku / Policzek przy udzie” 
[Tlen, T], wpatrzeni w rozgwieżdżone niebo wyobraźnią chwytamy gwiazdy: „Pokażę ci miłość w jednej garści gwiazd” [Tlen, $\mathrm{T}]$. Zapisem miłosnego pragnienia-spełnienia jest apostrofa do Wiosny w wierszu Deszcz [Tt] - miłosne soki animizowanej (nie personifikowanej) Wiosny „płyną po palcach drzew”, „pocałunki mnożą się jak motyle”, w objęciach jej ramion „spadam” (w otchłań/orgazm). Sytuacja miłosnego zbliżenia wyraźnie eksponuje wspólistnienie człowieka z wiosenną, burzową energią. Znamienne, że poetka celowo eliminuje partnera: nie ktoś, ale „Coś mnie dzisiaj kocha” - mówi kochanka Wiosny, która kładzie się na trawie, „żeby być stworzeniem!”. Obrazowanie służy tutaj zatarciu granicy między wiosenną bio-energią przyrody i człowieka, co podkreśla taki komentarz: „Kto powiedzial / ludzkie? Kto / cokolwiek mówi?".

Miłosne związki z ziemią mają tu podwójną motywację: są ćwiczeniem wyobraźni ekologicznej, a także ratunkiem przed samotnością, ucieczką od trudnych związków partnerskich. Fiedorczuk powściąga emocje, nie pisze czułych erotyków. W pierwszych tomach (inaczej będzie w tu̇̇-tuż) mężczyzna, często depersonalizowany, pojawia się gdzieniegdzie jak rekwizyt codzienności, na przykład w szeregu różnych zajęć zajmuje miejsce pomiędzy malowaniem rzęs a kolekcjonerstwem: „maluję rzęsy / zdejmuję ubranie, obejmuję plecy mężczyzny / kolekcjonuję wizerunki aniołów" [Coś, T]. W świecie, w którym „nastąpił wielki wybuch” (aluzja do teorii narodzin świata, ale też do wojny), wszytko zostało tak „porozrzucane”, że trudno szukać Całości, Transcendencji, Sensu, trudno ten chaos porządkować. Ponieważ światem rządzi jakieś tajemnicze, nieznane, bezosobowe „Coś”, lekarstwem na ludzkie lęki są opowieści i „błogosławieństwo łez”: „a więc opowiadamy ciągle te same historie / coś się kończy zaczyna coś płonie / coś nas ku sobie popycha każe śpiewać" [Coś, T].

On - bez imienia i twarzy - pojawia się w jej świecie akcydentalnie i somatycznie, zawsze cielesny, jako potwierdzenie żywej, ciepłej obecności, na przykład w Zakłóceniach o świcie ona budzi się z lękiem i sprawdza, czy ciała utrzymują rytm oddechu: „i lgnę do twojego ciała / oddechu zdejmuję puls: / rytmiczny jak wiersz i wieczny" $[\mathrm{P}]$. Trudno doszukiwać się tutaj sytuacji erotycznej, 
bo kim jest „Ty”, nie wiadomo. Jest cieplym ciałem, oddychającym rytmicznie, przez rytm oddechu (wdech-wydech) zestrojonym z wiecznym „pulsowaniem” kosmosu. Oddychanie, pulsowanie, naturalne rytmy ciał to motywy pełniące tu funkcję "miłosnych” łączników człowieka z kosmosem. W świecie poetyckim Fiedorczuk czas mierzy się „pulsowaniem kry” [Kochankowie na otwartym morzu, 30], życie - pulsowaniem oddechu, a wiersze, które nieudolnie te rytmy imitują, są tylko echem prawdziwego życia:

Taki los: jesteś, ale cię nie ma.

Twoje sylaby są ciężką pracą żałoby.

Ponieważ znika się z niedoboru miłości

i nie ma mowy o nagości.

[Echo, P]

„Różnica pomiędzy wierszem a życiem jest zawsze absolutna” [Prosze powtarzać za mna, Tt], prawdziwe życie to „nagi”, zmysłowy dotyk ciała/skóry innego - ludzkiego czy nie-ludzkiego, ale zawsze ciała. Po stronie życia jest materia/energia, a drugiej strony nie ma, bo ludzkie nic (NIC, pustka) to powrót do niezróżnicowanej „ciemnej wody”. Metafory Fiedorczuk wyraźnie eksponują materialność każdego kontaktu. W wierszu Wyjście człowiek w kosmosie absolutnie samotny, zagubiony, „zarażony” chorobą na śmierć, osaczony przez „pustkę, której nikt nie widzi” - rozpaczliwe woła w mrok: „Kimkolwiek jesteś podaj mi swoje ciało języka i dnia”, „podaj mi swoje ciało nocy” [Tt]. W ostatnim tomie miłosne elegie ciemnieją, są podszyte katastroficznym przeczuciem ekologicznej katastrofy oraz metafizyczną rozpaczą: „My, zarażeni, musimy stale ponawiać wezwanie. / Inaczej znikniemy. / Wchłonie nas ciemna noc jeży i mrówek. [...] Więc pozwól, że ukocham twój mrok" [Wyjście, Tt].

Największą wartością jest miłość, bez miłości „ciało ulega atrofii, śmierć wchodzi na duszę" [Echo, P], a wiersze są melancholijną „pracą żałoby”, lekarstwem na pustkę i „niedobór miłości”. „Pod każdym wierszem plynie czarna rzeka” [Przecież, B] - snów, lęków i pragnień, których źródło bije w „samym brzuchu / Wielkiej ciemnej matki” [Przecież, B]. Metafora „czarnej rzeki” łączy odmienne 
porządki istnienia, kojarzy ekologiczną wyobraźnię poety z biologicznym, „podziemnym” nurtem życia planety.

Wielokrotnie, w różnych wariantach, powraca motyw pragnienia, głodu, niespełnienia, niezgody na kruchość istnienia i niemiłość. Tęsknota za miłością erotyczną, o jakiej Fiedorczuk częściej

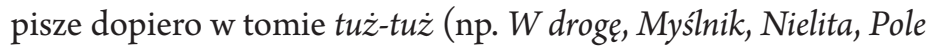
Mokotowskie), wybrzmiewa w ironicznej elegii miłosnej Wiersz [T]. Neutralny tytuł koresponduje z neutralną, pozornie obojętną relacją, w której konfrontacja marzeń z rzeczywistością wyraża się zderzeniem kulturowo odmiennych „wariantów”, różne poziomy organizacji tekstu ujawniają kontrast oczekiwań i spełnień. W trójdzielnym układzie różne „wersje” marzeń wprowadza trzykrotnie powtórzony motyw „pogubionych snów”: w wariancie pierwszym ona idzie do niego „przez las / przez świeżą zieleń doliny”, w drugim przez śmietnik: „reklamówki, plastikowe butelki, stare samochodowe fotele”, w trzecim „przez miasto”. „Jasnej” wizji nowoczesnego miasta (szkło, bezwonna stal, kolorowe światło) odpowiada cywilizacyjny śmietnik, a echo pierwszej pieśni miłosnej zabija współczesna, praktyczna definicja miłości:

mój miły jest mój a ja jestem jego

mamy psa lodówkę plazmę oraz buddę

miłość jest higieniczna dla zdrowia

i długowieczności

w tej wersji idę do ciebie przez wodę $\mathrm{i}$ tonę zanim się spotkamy.

[Wiersz, T]

Fragment wersetu 16 Pieśni nad Pieśniami pochodzi zapewne z tłumaczenia Czesława Miłosza: „Mój Miły jest mój, a ja jestem jego, który pasie między liliami” [Miłosz 1984: 32]. W tekście Fiedorczuk trudno przeoczyć formy osobowe czasownika „być”. Kochankowie biblijni są dla siebie i mają siebie nawzajem, natomiast kochankowie współcześni są tylko urządzeni, łączy ich wspólnota posiadania oraz świadomość higieny, zalecanej przez poradniki zdrowia. Współbycie kontrastuje tutaj z niebyciem, w zderzeniu z rzeczywistością rośnie wartość „pogubionych 
snów"/marzeń. Autorka Planety rzeczy zagubionych oprowadza nas po ludzkim świecie bez-dusznym, ekonomicznym, zorientowanym na pozorną wygodę ciała, pozorne korzyści, zalecane przepisy na „szlachetne zdrowie” (aluzja do fraszki Kochanowskiego

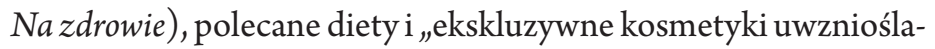
jące konsystencję" [To jest pierwszy dzień reszty twojego życia, T].

Współczesna humanistyka stopniowo likwiduje dualizm ciało - duch/dusza, posthumanistyczna antropologia kulturowa zajmuje się człowiekiem cielesnym, ale co z emocjami? Psychoterapeuci zalecają: wsłuchaj się w swoje ciało, odtruj organizm, zjednocz się z kosmosem - takie zalecenia zostają ironicznie skomentowane przez wiersze Fiedorczuk. Z czasem nieśmiało pojawia się pytanie o „ja”, a raczej „prawie ja”, ale to inny wątek, więc pozostanę przy wyraźnie manifestowanym somatyzmie, który w poezji kobiet ma długą tradycję. W sensualnych erotykach „zaczadzonej pięknem własnego ciała” Haliny Poświatowskiej dotyk „staje się sposobem pokonywania samotności przez nawiązanie kontaktu z Innym, i nie chodzi tylko o intymną bliskość drugiego człowieka. «Inne» to wszelkie formy otaczającej natury" [Legeżyńska 2009: 206]. Z kolei samozwrotne „ja” Anny Świrszczyńskiej, cofając się w głąb, od świata się oddala.

Implozja ciała jest rodzajem jego unicestwienia - pozbawienia biologicznej wagi, obecności - ale nie wskutek połączenia się z pierwiastkiem zewnętrznej materii, lecz dzięki uzyskaniu, mówiąc językiem fizyki, nieciągłości. Dzięki nie-byciu ciałem. [Legeżyńska 2009: 229]

W przypadku Fiedorczuk w ironicznych dialogach z nieokreślonym „kochankiem” trudno odnaleźć konsekwencję. Kontakt z innym nie usuwa „ciemnych” (mortalnych, katastroficznych) myśli, nierzadko właśnie dotknięcie ciepła wyzwala lęk przez chłodem. Z dojmującym poczuciem braku, lęku przed śmiercią i zagładą świata koresponduje chwiejna kondycja podmiotu. „Ja" rozbite, śmietnikowe często wypowiada się składanką cytatów pochodzących z literatury, filozofii, Wikipedii, reklamy. Trafnym określeniem takiej kondycji jest neologizm „nielita”, będący prze- 
ciwieństwem tego, co oznacza „lity” (zwarty, jednolity): „nielita // a namacalna, i gdyby nie «ty», / jak drzewo w środku łagodnego lasu" [nielita, Tt]. Psychofizycznie niejednolita, ale namacalna, materialnie stabilna (ten aspekt poetka konsekwentnie podkreśla) żyłaby sobie życiem rośliny (jak drzewo), gdyby nie miłość. Z konieczności pomijam wiersze Skośni kochankowie [P], Kochankowie na niebieskim tle $[\mathrm{P}]$ i liczne fragmenty z odesłaniem do różnych tekstów kultury (wierszy, obrazów), których bohaterami są właśnie kochankowie.

Nieskłonna do dywagacji filozoficznych Fiedorczuk stale powtarza dwie tezy: po pierwsze - sens istnieniu nadaje miłość (,jesteśmy”, bo kochamy), po drugie - przedmiotem naszej troski ma być wszystko, co żywe. W erotyku Nielita z myślą o nie-ludzkim innym wiąże się poczucie winy wobec mieszkańców mchu, tratowanych przez kochanków, którzy w miłosnym zapamiętaniu zapominają o „maleństwach”: „bez jednego westchnienia dla maleństw / ucztujących bez wina na ciele / ogromnym bez płci”.

$\mathrm{Z}$ każdym kolejnym tomem gęstnieje aura elegijności: ciemność, pustka, śmierć, bolesne „opukiwanie pustki” [It has been player once more, $\mathrm{T}]$. O czym rozmawia matka $\mathrm{z}$ dzieckiem? $\mathrm{O}$ snach, duchach, śmierci i nicości. W sypialni opowiadają sobie sny (z freudowskim komentarzem), w drodze do przedszkola bawią się, że jedna z nich nie żyje. Wszystkie wiersze z córką/ córeczką są podszyte lękiem, grozą (urodziłam istotę skazaną ...) i bezradnością matki, która nie wie, jak odpowiadać na trudne pytania: „córka pyta: mamusiu, a co to jest nic? / nic takiego, kochanie, odpowiadam, śpij” [Burze i przejaśnienia, T].

Życiu-podróży znikąd donikąd towarzyszy poczucie utraty, zguby, elegijna świadomość tego, że „[w] szystko jest pożegnalne”jak czytamy w wierszu Spis strat (i zysków), zamykającym tom Planeta rzeczy zagubionych. Wiersz Kochankowie na otwartym morzu zawiera na końcu wyznanie skierowane do nieokreślonego adresata - kogoś, na kogo się czeka (człowiek, świat, życie): „teraz jestem twoja, należę do ciebie, należę do morza, do ziemi, do ciebie” [P].

Podążając $\mathrm{w}$ ślad za poetką, nurzam miłość $\mathrm{w}$ antropogenie. Mając na uwadze fizjologiczny i cielesny charakter każdego „związku miłosnego”, uwzględniam wszystkie miłości, które znaj- 
duję w poezji Fiedorczuk. Jedną z nich można by za „ojcem bioróżnorodności” Edwardem Osborne’em Wilsonem nazwać biofilią, czyli „miłością do pozaludzkiej natury” [Fiedorczuk 2015a: 236]. Człowieka w tym świecie mniej dotyka obojętność przyrody (ten dystans pokonuje dzięki wyobraźni), bardziej boli go wspólne znikanie, przemijanie, nicestwienie.

W poezji Fiedorczuk niezgodę na urządzenie świata łagodzi deklarowany eko-program, w którym „ja” stara się lekceważyć „ludzkie” pretensje, a nawet - co jest niemożliwe - próbuje zniknąć, ukrywa swoją „odrębność” i „pojedynczość”. Przyjmując program wymierzony przeciw kulturowemu, antropocentrycznemu zamknięciu, autorka Bio konsekwentnie unika symboliki biblijnej. Z Ziemiomorza wybiera tylko byty bezimienne, ryby - mieszkanki żywiołu otwartego, których nie można spętać „ludzkimi” czarami jakiejkolwiek kultury. W tych „ekowierszach” obrazowanie sprzyja zacieraniu różnic pomiędzy ciałem człowieka i ciałem świata: „Zapuściłam / Skrzydła jak liście // Czarnych paproci” [Bio, B], „gniazdo w zgięciu ramion tamtej grubej sosny, / w gnieździe moich ramion mleczny oddech dziecka” [Tlen, T]. Planetę rzeczy zagubionych otwiera wiersz, w którym poetka zamazuje różnicę między żywiołami: ogień odczuwany „w podeszwach stóp” jest znakiem tego, „że kiedyś wszystko było boskim oceanem” [Lądy i oceany, P]. Powszechnie znaną teorię początku (życie wyszło z wody) i ustalenie wieku naszej planety - odkrycie, które „odmieniło bieg ludzkiej myśli” - Fiedorczuk przeciwstawia bezpośredniej komunikacji somatycznej. Sugeruje (może za ustaleniami biosemiotyki?), że o pradziejach planety informuje ciało (wysyła znaki, których nasz intelekt nie rozpoznaje), na przykład łzy przechowują pamięć oceanicznej soli ... Metafora „rzeczy zagubionych” dobrze zapowiada elegijną aurę tomu i „słoną” akceptację praw obowiązujących na Ziemi: „Tak czy inaczej, odmęt ma swoje prawa. / Ciała poniekąd stałe, mamy przecież łzy, a te są w każdym słowie: / bo sól jest na końcu języka i jest kropką nad i” [Lądy i oceany, P].

Puenta, zbudowana na kontaminacji zwrotów frazeologicznych („na końcu języka”, „kropka nad i”), demonstruje cielesność języka, jest próbą zatarcia różnicy między planetą, ciałem i emocjami. Na „odmęt” człowiek odpowiada łzą - ciało produkuje łzy, 
poeta płacze słowem. Mieszkaniec „planety rzeczy zagubionych” troską i żalem obejmuje wszystkie istoty żywe, zwłaszcza te pomijane, od wieków rozdeptywane (owady, robaki). Poetyckie „eko-spojrzenie" Fiedorczuk kieruje w stronę chrząszcza, rozwielitki, meduzy, na przykład w Plaży „brązowe meduzy wysychają w stadach [...] smażą się w słońcu / po egzekucji / z tłuszczem wsiąkają w piach" $[\mathrm{P}]$. W tekście, który koresponduje z Meduzq Marianne Moore, zauważam intertekstualny dialog z poezją szukającą łączności z „ciałem świata” (za Merleau-Pontym tak to określa Fiedorczuk [2015b: 69]). W cytowanym wierszu egzekutorem meduz jest życiodajne słońce. Gdy człowiek próbuje wrzucić meduzy z powrotem do morza, ich rozpadające się ciała i wypływające na palce wnętrzności wywołują szok. Opowiedziane w wierszu spotkanie z meduzami to bezpośredni, cielesny kontakt ze śmiercią istoty nie-ludzkiej. Na początku podmiot mówi o nich językiem gastronomii (niejadalne, smażą się, wsiąkają z tłuszczem), w dalszych partiach wiersza jak litanijny refren powtarza się formuła liczenia (,jedna meduza / druga meduza...”), a w finale - kiedy wszystkie meduzy zostały pochowane - pojawia się żałobna antropomorfizacja. Ich „głowy / posypane piaskiem” przypominają ludzkie ciała „przysypane ziemią", ale też głowy „posypane popiołem”. Podstawę empatycznej łączności ze światem stanowi wyobraźnia, jest ona „tym, co łączy przyrodnika, poetę, wynalazcę, biznesmena $[\ldots]$, podstawowym warunkiem dialogu, umożliwia wyjście poza ciasne więzienie «ja»” [Fiedorczuk 2015b: 69-70].

Mając na uwadze krytycznoliterackie wypowiedzi Fiedorczuk, zwłaszcza jej pozytywne nastawienie do ekofeminizmu, trudno pominąc światopogląd materialistyczny i związek z posthumanizmem. O więzi człowieka z pejzażem autorka mówi czasem w terminach sakralnych („duch świata”, budda, boginie hinduskie), lecz zasadniczo zawsze poruszamy się w świecie materii. Trzeba też pamiętać o specyfice wypowiedzi elegijno-ironicznej czy autoironicznej, miksującej cytaty i dyskursy [Burze i przejaśnienia, T].

Z jednej strony szacunek dla nauki (współczesna encyklopedia fizyki i przyrody), a z drugiej prywatny „panteizm”. Przywołani „bogowie” funkcjonują w wierszach jako znaki kulturowe (łączy ich zmysłowość), bo praktyka poetycka Fiedorczuk zmierza do 
pokonania dystansu dzielącego światy: ludzki i nie-ludzki. Podmiot bywa rozdarty między chłodną, racjonalną akceptacją praw, którymi rządzi się przyroda, a potrzebami psychiki, emocjami, na które dawniej odpowiadały religie i mitologie. Zniesienie opozycji: przyroda - kultura nie może się udać, niemniej jednak odbiorca powinien zauważyć wysiłek zacierania tych odrębności (w kulturze Zachodu - fundamentalnych) i docenić zmagania poetki z tradycyjnym, odwiecznym paradygmatem myślenia o sposobach zamieszkiwania. Odrzucając Heideggerowskie „być - mieszkać budować”, Fiedorczuk nie proponuje powrotu do istnienia „roślinnego” czy „zwierzęcego”, ona melancholijnie i rozpaczliwie próbuje zaakceptować prawo natury. A taka postawa kłóci się z wrażliwością człowieka, który ceni każde życie - planety, jeża i meduzy.

Obiektem miłosnym, oprócz mężczyzny, są tutaj żywioły, drzewa, rozmaite istoty żywe. Fiedorczuk tak kojarzy różne porządki, że odbiorca nie wie, kim jest „ty” (elementem środowiska naturalnego czy osobą?), i to zacieranie pełni ważną funkcję, jest znakiem „wtapiania się” w „bio-tkankę”. Dyskretna i powściągliwa autorka trudną miłość do świata naturalnego wypowiada metapoetycko, sugerując wzajemne „cielesne” spotkania. Przyroda działa na zmysły, natomiast ekopoetka, niejako w rewanżu, uderza w „ciało świata”, stosując gry poetyckie:

Przytul mnie ziemio, kreseczkę nad erotycznym „eś” świata i śmierci. Trawo truskawko, mam

Wszystkie twarde sylaby, nawzajem się

Nimi szturchamy. [...

[Nowa wiosna, B]

„Ja” poetycko definiowane jako kreseczka nad erotycznym „eś” świata i śmierci to koncept zmiękczający, ocieplający pierwszą literę, która stanowi o ich podobieństwie. Zwróćmy uwagę na charakterystyczną (obecną w programie ekopoetyki) materialność, cielesność języka. Użytkownik języka dysponuje miękkim „ś” oraz twardymi sylabami, którymi nawzajem cieleśnie „szturchają się” człowiek i byty roślinne. "Ja” twardo brzmiącym słowem-znakiem „twardo” dotyka trawy i truskawki (powtarzają się głoski „t” i „r”), a trawa 
i truskawka atakują zmysły wzroku, smaku, dotyku. Ta wzajemność dotyków przenosi się dalej, poza ludzkie życie, bo kiedy ziemia przytula martwe ciało, ono dostarcza treści organicznych innym istotom. Fiedorczuk często wprowadza „maleństwa”, czyli istoty przy-ziemne lub pod-ziemne (jeże, krety, niezidentyfikowanych mieszkańców leśnego czy ogrodowego podłoża), żywiące się padliną.

Źródłem elegijności jest tutaj lęk przed zapominaniem, utratą tego, co stanowi o naszym człowieczeństwie. Kolejnym stałym motywem jest pająk (pajęczyny na drzewach, Arachne na niebie, Arachne - figura kobiecego pisania, pająki w głowie), „głodnej Arachne" (to metafora wszystko pochłaniającej Nocy) odpowiada poetka pajęczyca, która mozolnie plecie swoją tkaninę - splata myśli z myślami innych poetów oraz z tym, co nie-ludzkie, co poza nami. (To sygnał, by łączyć ekokrytykę z arachnologią). Dotychczasowe wnioski można spuentować, używając stosowanych przez Fiedorczuk słów kluczy: bohaterka liryczna tej poezji, oddychając tlenem, żywi bio-tkankę, dzięki której tka, by zatrzymać świat w słowach. Laicki światopogląd wyklucza nadzieję na wieczność, a poczucie organicznej więzi z innymi organizmami sprzyja medytacji akceptującej, a zarazem opłakującej śmierć każdego stworzenia.

Ekomyślenie ma określone konsekwencje etyczne, wyklucza wrogość i obojętność wobec nie-ludzkiego. Z trudną zgodą na przemijanie współgra miłosna elegia ziemi. Fiedorczuk obywa się bez mitów (w rodzaju Matka Ziemia), anihiluje Historię, raczej unika kwestii społecznych czy politycznych. Przedmiotem elegijnej medytacji jest relacja „ja” wobec kosmosu, planety, bliskich. „Ja” prywatne, tożsame z autorką, wyposażone w jej wrażliwość i wiedzę o świecie.

Zgodnie z przyjętym programem ekopoezji i ekokrytyki w miejsce mitów Fiedorczuk wprowadza „twardą” wiedzę z zakresu biologii czy chemii, co sygnalizują w wierszach terminy naukowe. I nie są to puste stylizacje, lecz próba zasypania przepaści pomiędzy nauką i poezją, próba łączenia istnienia psychosomatycznego z materialnością języka. Czy udana - to osądzi czytelnik. Czytałam te wiersze z trudem. Nie rozumiem biosemiotyki, nie starcza mi wyobraźni, która pozwala swobodnie przechodzić od „wewnątrz” do „zewnątrz” i z powrotem. I choć przeraża mnie miłość do tego, 
co „ciemne”, „żywe”, „głodne”, doceniam poetyckie zmagania z niewyrażalnym. Za jeden z najlepszych wierszy uważam pięknie utkane pożegnanie:

ciemne się zbiera w zagłębieniach ciała nas porasta.

nam odejmuje słowa ku uciesze dłoni.

bo żywe tłoczy się w parterze i węszy.

głodne.

[... ciemne nas wypełnia aż po marginesy.

$[\ldots]$

tuż-tuż na wyciągnięcie ręki, żywy pępek snu.

[Dobranoc, T]

\section{Skróty}

B - Julia Fiedorczuk, Bio

P - Julia Fiedorczuk, Planeta rzeczy zagubionych

$\mathrm{T}$ - Julia Fiedorczuk, Tlen

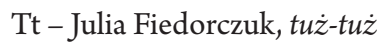

\section{Bibliografia}

Barcz Anna (2016), Realizm ekologiczny. Od ekokrytyki do zookrytyki w literaturze polskiej, Wydawnictwo Naukowe „Śląsk”, Katowice.

Czapliński Przemysław (2012), Literatura i życie. Perspektywy biopoetyki, w: Teoria, literatura, życie. Praktykowanie teorii $w$ humanistyce wspótczesnej, red. Ryszard Nycz, Anna Legeżyńska, Instytut Badań Literackich PAN, Warszawa.

Fiedorczuk Julia (2004), Bio, Biuro Literackie, Wrocław.

Fiedorczuk Julia (2006), Planeta rzeczy zagubionych, Biuro Literackie, Wrocław.

Fiedorczuk Julia (2009), Tlen, Biuro Literackie, Wrocław.

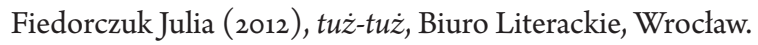

Fiedorczuk Julia (2015a), Cyborg w ogrodzie. Wprowadzenie do ekokrytyki, Wydawnictwo Naukowe Katedra, Gdańsk. 
Fiedorczuk Julia (2015b), Złożoność nie jest zbrodnią. Szkice o amerykańskiej poezji modernistycznej i postmodernistycznej, Wydawnictwa Uniwersytetu Warszawskiego, Warszawa.

Fiedorczuk Julia, Beltrán Gerardo (2015), Ekopoetyka. Ekologiczna obrona poezji, Muzeum Historii Polskiego Ruchu Ludowego (Warszawa), Instytut Studiów Iberyjskich i Iberoamerykańskich uw, Warszawa. Jackson (Riding) Laura (2012), Obroty cudów, wybór, przekład i posłowie Julia Fiedorczuk, Biuro Literackie, Wrocław.

Księgi Pięciu Megilot (1984), przeł. z hebrajskiego i greckiego Czesław Miłosz, Katolicki Uniwersytet Lubelski, Lublin.

Le Guin Ursula K. (2013), Ziemiomorze, przeł. Stanisław Barańczak, Prószyński Media, Warszawa.

Legeżyńska Anna (2009), Od kochanki do psalmistki. Sylwetki, tematy i konwencje liryki kobiecej, Wydawnictwo Poznańskie, Poznań.

\section{Anna Węgrzyniak}

\section{Exercising ekological imagery. On Julia Fiedorczuk's poetry}

The key to reading Julia Fiedorczuk's poems - interpreted within the paradigm of eco-poetry - are the words used in the titles of her poetry volumes: "bio", "planet" and "oxygen", which foretell bio-centrism. The poetic imagery unites organic tissues with the artist's "texture". A love relationship of a human with a non-human reveals ecological sensitivity, yet it is a painful "love" because it is accompanied by the disagreement about the fragility of existence and the progressing degradation of the planet.

Keywords: eco-poetry; organism; elegy.

Anna Wegrzyniak - prof. dr hab., kierownik Katedry Literatury i Kultury Polskiej w Akademii Techniczno-Humanistycznej w Bielsku-Białej. W latach 1974-2003 zatrudniona na Uniwersytecie Śląskim, od 2002 jest pracownikiem Akademii Techniczno-Humanistycznej w Bielsku-Białej. W latach 20062012 kierowała Katedrą Kulturoznawstwa w Wyższej Szkole Zarządzania Ochroną Pracy w Katowicach. W latach 2003-2015 była redaktorką naczelną pisma naukowego „Świat i Słowo”. Autorka prac o poezji i prozie Xx i XXI wieku. Ważniejsze publikacje: Nie ma rozpusty większej niż myślenie: o poezji Wisławy Szymborskiej (1996), Egzystencjalne i metafizyczne: od Leśmiana do Maja (1999), Czytam więc jestem: studia, interpretacje, glosy (2004), Ja głosów świata imitator: studia o poezji Juliana Tuwima (2005). 
